\title{
Thermal analysis of W-free Co-(Ni)-Al-Mo-Nb superalloys
}

\author{
Damian Migas $^{1}$ [D $\cdot$ Grzegorz Moskal $^{1} \cdot$ Tomasz Maciąg $^{2}$
}

Received: 16 August 2019 / Accepted: 21 January 2020 / Published online: 24 February 2020

(c) The Author(s) 2020

\begin{abstract}
In this investigation, the thermal analysis of $\mathrm{W}$-free cobalt-based superalloys based on $\mathrm{Co}-\mathrm{Al}-\mathrm{Mo}-\mathrm{Nb}$ and $\mathrm{Co}-\mathrm{Ni}-\mathrm{Al}-$ $\mathrm{Mo}-\mathrm{Nb}$ systems was performed. The analysis was performed at different stages of heat treatment process. The differential thermal analysis (DTA) was utilized for the determination of characteristic temperatures related to microstructural changes. First of all, the DTA analysis was carried out for discussing as-cast alloys in the temperature range of $40-1500{ }^{\circ} \mathrm{C}$. The results showed thermal effects connected with melting and important order-disorder transition. The temperature range of $1200-1250^{\circ} \mathrm{C}$ was chosen for performance of a first heat treatment operation for the investigated alloys. Specimens were annealed at selected temperature for $5 \mathrm{~h}$. The microstructure of alloys after solution heat treatment was analyzed as well. Afterward, the solutionized specimens were subjected to the further thermal analysis in order to select the aging temperature according to the order-disorder transformation related to formation of $\gamma^{\prime}$ phase with overall formula $\mathrm{Co}_{3}(\mathrm{Al}, \mathrm{X})$. Five aging variants were performed in the temperature range of $800-1000$ with a step of $50{ }^{\circ} \mathrm{C}$. After each stage of heat treatment, SEM/ EDS analysis and hardness measurements were performed.
\end{abstract}

Keywords $\gamma / \gamma^{\prime} \cdot$ Precipitation hardening $\cdot \mathrm{W}$-free superalloys $\cdot$ Cobalt $\cdot$ DTA

\section{Introduction}

The starting point of development of the new creep-resistant materials based on Co was discovery of the two-phase area in the ternary system Co-Al-W. This field consists of $\gamma$ matrix based on Co with fcc type of lattice and $\mathrm{L}_{2}$ intermetallic phase with overall formula $\mathrm{Co}_{3}(\mathrm{Al}, \mathrm{W})$. This fact gets the possibility of creation of a new group of Co-based superalloys strengthened by $\mathrm{L}_{2}$ intermetallic phase with microstructure very similar to conventional Ni-based superalloys of $\gamma / \gamma^{\prime}$ type [1,2]. There are two basic groups of these alloys at this time. First of them is based on tungsten addition and $\mathrm{Co}_{3}(\mathrm{Al}, \mathrm{W})$ phase as a strengthening structural element. The second group is called $\mathrm{W}$-free alloys and consists

Damian Migas

damian.migas@polsl.pl

1 Department of Advanced Materials and Technologies, Faculty of Materials Engineering, Silesian University of Technology, Krasińskiego 8 St., 40-019 Katowice, Poland

2 Department of Metallurgy and Recycling, Faculty of Materials Engineering, Silesian University of Technology, Krasińskiego 8 St., 40-019 Katowice, Poland of other high melting point elements such as $\mathrm{Mo}, \mathrm{Nb}$ and $\mathrm{Ta}$ as elements forming the desirable $\mathrm{Co}_{3}(\mathrm{Al}, \mathrm{X})$ phase $[3,4]$.

There are many articles related to those alloys, focused on microstructure, mechanical properties, oxidation, creep resistance and the influence of quaternary and quinary alloying elements on those properties. However, in the literature data exists relatively low information about heat treatment parameters and such processes as homogenization solutionizing and aging [5-12]. Only in few publications, it is possible to find the information about the influence of alloying elements on solidus temperature of Co-Al-W alloys, and especially solvus temperature of strengthened structural elements of $\mathrm{L}_{2}$ type. This information is related mainly to $\mathrm{W}$ and $\mathrm{Al}$ concentration and eventually to $\mathrm{Ni}$ addition as an alloying element.

This article concerns the influence of W-replacement by $\mathrm{Mo}$ and $\mathrm{Nb}$ on the thermal effects in Co-based superalloys. Some data regarding W-free superalloys are available in the literature $[3,13,14]$. The similar alloys based on $\mathrm{Co}-\mathrm{Al}-\mathrm{Mo}-\mathrm{Nb}$ and $\mathrm{Co}-\mathrm{Ni}-\mathrm{Al}-\mathrm{Mo}-\mathrm{Nb}$ systems were prepared by induction vacuum melting. The thermal analysis of discussed superalloys was performed in as-cast state as well as on further stages of heat treatment. Moreover, after each heat treatment step, the microstructure of alloys was 
investigated. The influence of $\mathrm{W}$-replacement on thermal behavior of Co-based alloys including determination of soli$d u s$ and solvus temperatures was analyzed.

\section{Materials and methods}

The $\mathrm{Co}-10 \mathrm{Al}-5 \mathrm{Mo}-2 \mathrm{Nb}$ and $\mathrm{Co}-20 \mathrm{Ni}-10 \mathrm{Al}-5 \mathrm{Mo}-2 \mathrm{Nb}$ (at\%) alloys were melted using induction vacuum furnace VSG 02 Balzers and cast under Ar atmosphere. Pure metals were used in the investigation, including Co ( $\mathrm{min} .99 .98 \%$ ), $\mathrm{Al}$ (99.98\%) Mo (99.98\%) and $\mathrm{Nb}$ (99.99). Mo and $\mathrm{Nb}$ were being dosed to liquid bath of $\mathrm{Co}$ and $\mathrm{Al}$. The alloys were melted in the temperature range of $1600-1700{ }^{\circ} \mathrm{C}$ for the time of approx. $10 \mathrm{~min}$. The investigated alloys were cast into cold graphite molds under the protective gas (Ar). The time of solidification did not exceed $10 \mathrm{~s}$. In the next step, metal pieces were cut from the cast ingot; samples for heat treatment investigations were prepared. The solution heat treatment was performed at $1200^{\circ} \mathrm{C}$ for $5 \mathrm{~h}$ with subsequent quenching in water. The solution heat treatment operation was carried out in a laboratory furnace with the Ar protection atmosphere. Afterward, the solutionized specimens were subjected to aging at temperatures of $800,850,900$, $950,1000{ }^{\circ} \mathrm{C}$ for $5 \mathrm{~h}$ in the $\mathrm{Ar}$ atmosphere with final water quenching.

The thermal analysis including differential thermal analysis (DTA) was carried out on the as-cast, solutionized and aged specimens. The DTA analysis was carried out using the NETZSCH STA 449 F3 Jupiter thermal analyzer. The temperature range of analysis was $40-1500{ }^{\circ} \mathrm{C}$ of heating and cooling rate $20{ }^{\circ} \mathrm{C} \mathrm{min}^{-1}$. As a reference, an empty alumina crucible was used. Additionally, differential scanning calorimetry (DSC) was used in order to investigate temperature of order-disorder transformation in alloys. The measurements in the temperature range of $40-1200{ }^{\circ} \mathrm{C}$ were performed using multi-HTC high-temperature calorimeter from Setaram. The measurements were performed under the Ar protection; the heating rate was $5{ }^{\circ} \mathrm{C} \mathrm{min}^{-1}$.

The specimens for microstructure evaluation were prepared by grinding, polishing and chemical etching. In the case of as-cast and as-solutionized samples, a reagent containing $25 \mathrm{~mL} \mathrm{H}_{2} \mathrm{O}, 50 \mathrm{~mL} \mathrm{HCl}, 15 \mathrm{~g} \mathrm{FeCl}_{3}$ i $3 \mathrm{~g}$ $\mathrm{CuCl}_{2} \times \mathrm{NH}_{4} \mathrm{Cl}_{2} \times \mathrm{H}_{2} \mathrm{O}$ was used for etching. The specimens after aging were chemically etched using reagent containing $80 \mathrm{~mL}$ of lactic acid, $10 \mathrm{~mL}$ of $\mathrm{HNO}_{3}$ and $10 \mathrm{~mL}$ of $\mathrm{H}_{2} \mathrm{O}_{2}$, The as-cast microstructure was analyzed by means of optical microscopy (OM), scanning electron microscopy (SEM) and X-ray diffraction (XRD). The optical micrographs were performed using the Nikon Eclipse MA200 microscope. In the case of SEM/EDS analysis, the scanning electron microscope (SEM, Hitachi S-3400 N) equipped with the energy dispersion spectrometer (EDS, Thermo
Noran System Seven) was utilized. The phase composition was evaluated using Phillips $\mathrm{X}^{\prime}$ Pert $^{3}$ Powder diffractometer. Furthermore, hardness of specimens was investigated by Vickers method. The measurements were performed using the ZWICK ZHV TKV5030 Vickers hardness tester using a load of $2.5 \mathrm{~kg}$. The analogous research methodology was utilized for the specimens after solution heat treatment and aging.

\section{Results and discussion}

The first part of work concerns concise description of the as-cast microstructure of investigated alloy. In the case of $\mathrm{Co}-10 \mathrm{Al}-5 \mathrm{Mo}-2 \mathrm{Nb}$ (at\%) alloy, the characterization of primary microstructure is available [15], whereas the ascast microstructure of second alloy is similar. The $\mathrm{OM}$ and SEM micrographs of investigated alloys in the as-cast state can be observed in Fig. 1. Both alloys are characterized by a dendritic microstructure, typical for the castings made with high cooling rate. For cobalt alloys in which $\mathrm{W}$ was replaced by $\mathrm{Mo}$ and $\mathrm{Nb}$, occurrence of some eutectic phases in the interdendritic regions may be observable (phases are indicated by white arrows). Taking into account the chemical and phase composition of the alloys after casting (Fig. 2), the interdendritic spaces may be enriched in $\mathrm{Co}_{3} \mathrm{X}$ phases (where $\mathrm{X}=\mathrm{Mo}, \mathrm{Nb}$ ). Such phases were detected via $\mathrm{X}$-ray diffraction analysis. For the alloy with composition $\mathrm{Co}-20 \mathrm{Ni}-10 \mathrm{Al}-5 \mathrm{Mo}-2 \mathrm{Nb}$ (at\%), peaks related to the
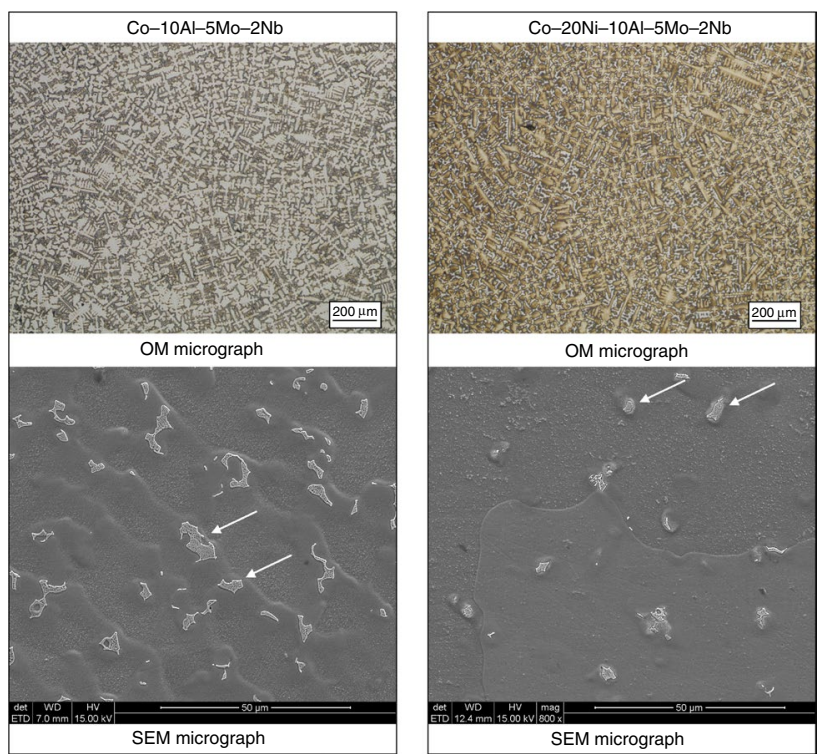

Fig. $1 \mathrm{OM}$ and SEM images of primary microstructure of $\mathrm{Co}-(\mathrm{Ni})$ $\mathrm{Al}-\mathrm{Mo}-\mathrm{Nb}$ alloys 


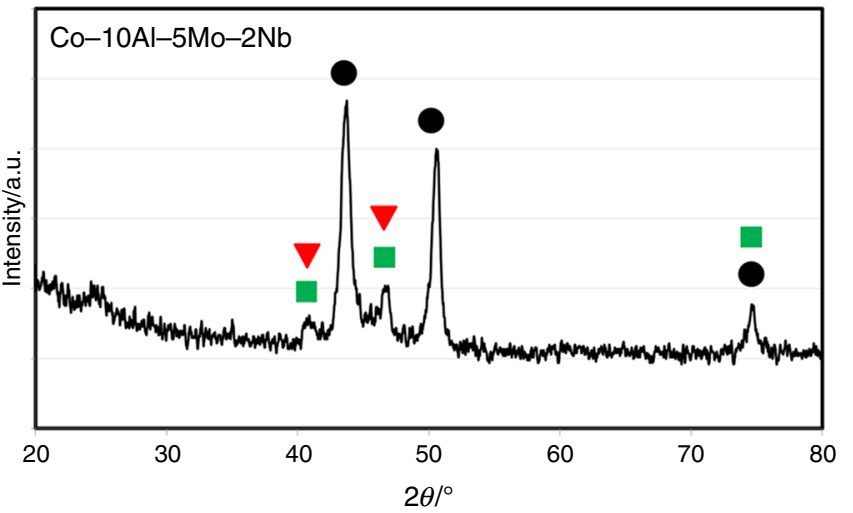

$\mathrm{Co}_{3} \mathrm{Nb}$ (JCPDS no 19-0355)

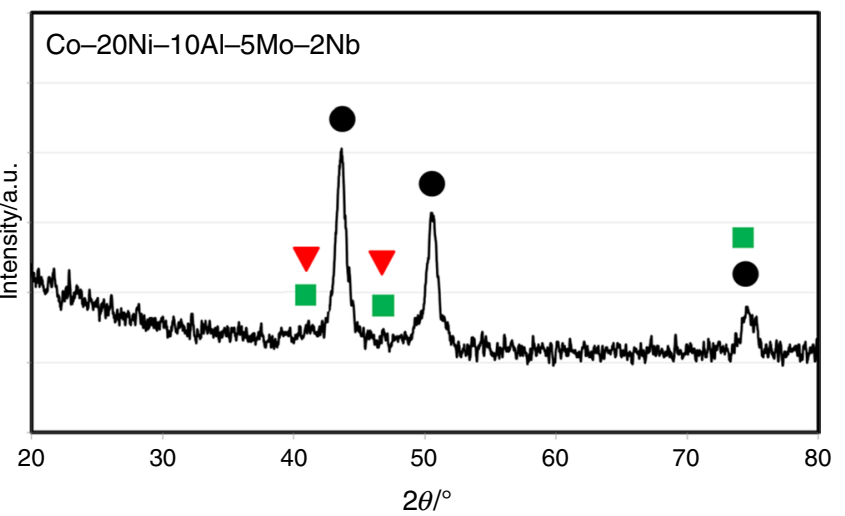

$\mathrm{Co}_{3} \mathrm{Mo}$ (JCPDS no 29-0488)

Fig. 2 X-ray diffraction patterns $\mathrm{Co}-(\mathrm{Ni})-\mathrm{Al}-\mathrm{Mo}-\mathrm{Nb}$ alloys in as-cast state

discussed phases are lower compared to those of Ni-free alloy. Furthermore, the microstructural analysis showed lower concentration of the interdendritic precipitates for alloy with $\mathrm{Ni}$ compared to that of $\mathrm{Co}-10 \mathrm{Al}-5 \mathrm{Mo}-2 \mathrm{Nb}$ (at\%).

After short characterization of the as-cast microstructure, the analyzed castings were subjected to the differential thermal analysis. Figure 3 shows the DTA curves corresponding to the first, Ni-Free alloy. The heating curve did not show any distinct thermal effects up to $1300{ }^{\circ} \mathrm{C}$. One
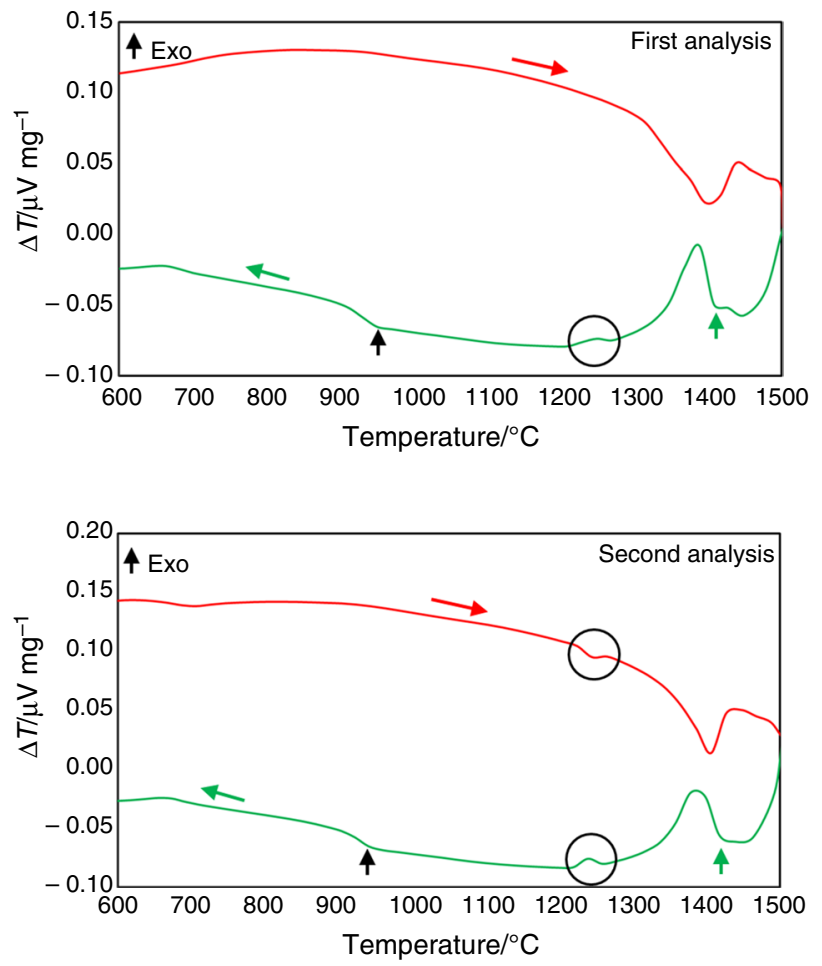

Fig. 3 Differential thermal analysis of $\mathrm{Co}-10 \mathrm{Al}-5 \mathrm{Mo}-2 \mathrm{Nb}$ alloy in as-cast state substantial endothermic effect that corresponds to the melting point of alloy may be visible in the temperature range of $1300-1400{ }^{\circ} \mathrm{C}$. However, the course of DTA curve in this range is not sharp; therefore, the accurate determination of melting temperature could be difficult. More information concerning the thermal behavior of alloy is shown by the cooling curve. Except the liquidus temperature (marked by green arrow), the green DTA plot allows to observe two exothermic effects; the first one started at $1268{ }^{\circ} \mathrm{C}$ (effect is indicated by black circle), whereas the second one at $950{ }^{\circ} \mathrm{C}$ (effect is indicated by black arrow). The first thermal effect is connected with precipitation of some phase. At comparable temperature $\left(1231{ }^{\circ} \mathrm{C}\right)$ takes place the eutectic reaction in $\mathrm{Co}-\mathrm{Nb}$ system [16]:

$\mathrm{liq} \rightleftharpoons \mathrm{fcc}+\mathrm{Co}_{3} \mathrm{Nb}$

The second thermal effect observed at $950{ }^{\circ} \mathrm{C}$ is typical for precipitation of the $\gamma^{\prime}$ phase that was observed in other publication [12]. Afterward, the analyzed specimen was subjected to the another DTA experiment under the same conditions. The course of both heating and cooling plots was comparable to that of the plots from first analysis; however, one exception occurred. The heating plot exhibits some endothermic effect at $1244^{\circ} \mathrm{C}$. Moreover, the cooling curve shows reversible effect, which is very similar to the effect that occurred in the first analysis (at $1268{ }^{\circ} \mathrm{C}$ ). These results imply that the phase which precipitated at $1268^{\circ} \mathrm{C}$ in the first analysis was dissolved at $1244^{\circ} \mathrm{C}$ in the second analysis and then again precipitated in the cooling process.

Figure 4 shows DTA analysis of Co-20Ni-10Al-5Mo-2Nb (at\%) alloy. The course of DTA curves is similar to that of Ni-free alloy; however, no effects connected with precipitation or dissolution of phases were observed above $1200^{\circ} \mathrm{C}$. The same observation may be done after observation of the second analysis. The 

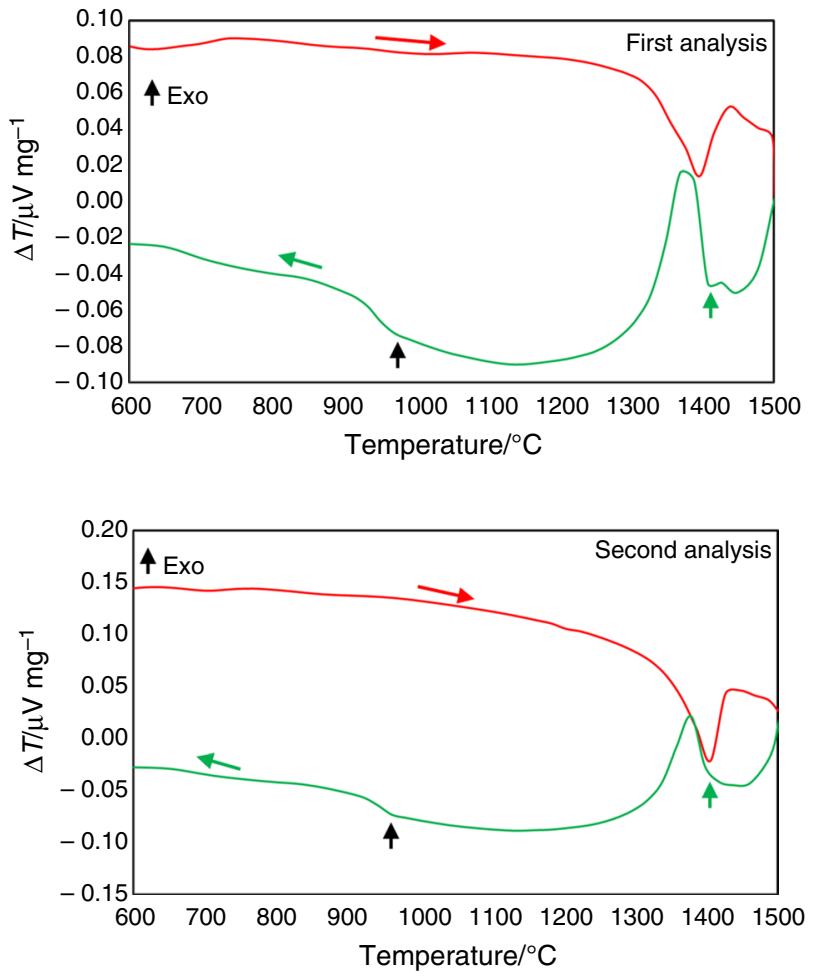

Fig. 4 Differential thermal analysis of $\mathrm{Co}-20 \mathrm{Ni}-10 \mathrm{Al}-5 \mathrm{Mo}-2 \mathrm{Nb}$ alloy in as-cast state

temperature of the effect corresponding to $\gamma^{\prime}$ precipitation is comparable for both alloys.

Afterward, the W-free Co-based superalloys were solution heat-treated at $1200{ }^{\circ} \mathrm{C}$. The $\mathrm{OM}$ micrographs as well as SEM/EDS analysis of as-solutionized alloys are shown in Fig. 5. The micrographs made by optical microscopy show microstructure of the alloys after solution heat treatment. The as-solutionized alloys were characterized by grainy microstructure, whereas the size of grains was several hundred $\mu \mathrm{m}$. After solutionizing of the alloys at $1200{ }^{\circ} \mathrm{C}$, all phases observed in the as-cast state were dissolved which is confirmed by SEM micrographs. The measurement of chemical composition in micro-areas by EDS method shows that the chemical composition is in well accordance with the nominal one.

After the first heat treatment operation, the alloys were analyzed via DTA another time. Figure 6 shows the DTA plots corresponding to $\mathrm{Co}-10 \mathrm{Al}-5 \mathrm{Mo}-2 \mathrm{Nb}$ (at\%) in the as-solutionized state. The heating curve exhibits the endothermic effect at $866{ }^{\circ} \mathrm{C}$ that corresponds to order-disorder transformation related to the $\gamma^{\prime}$ phase. In the case of alloy after solution heat treatment, the melting effect is clearer and starts at $1313{ }^{\circ} \mathrm{C}$. Furthermore, the cooling plot shows an exothermic effect that starts at $1248^{\circ} \mathrm{C}$. This
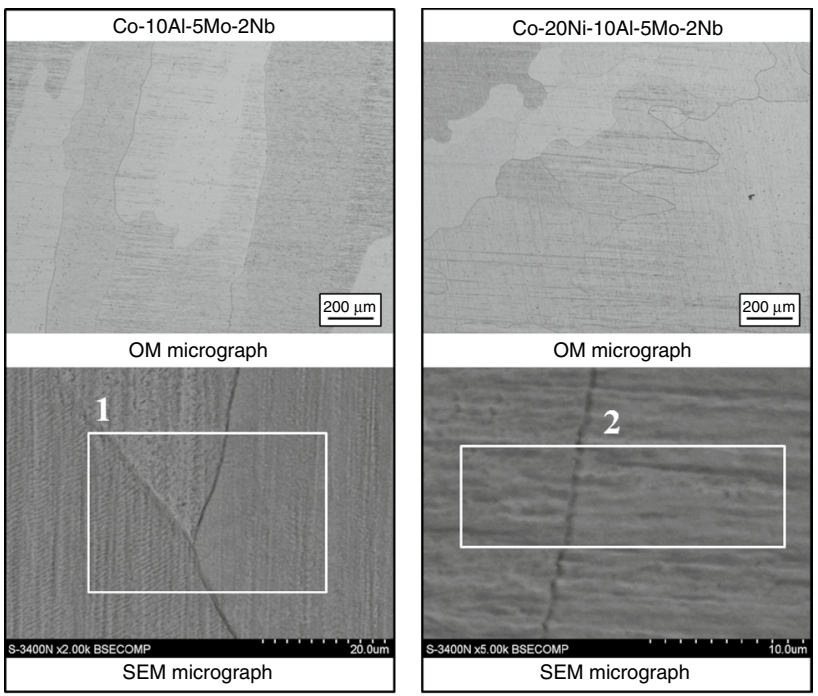

Chemical composition of arear marked above

\begin{tabular}{|c|c|c|c|c|c|}
\hline Atom\% & $\mathrm{Al}$ & $\mathrm{Co}$ & $\mathrm{Ni}$ & $\mathrm{Mo}$ & $\mathrm{Nb}$ \\
\hline Area 1 & 9.9 & 82.5 & - & 5.1 & 2.5 \\
\hline Area 2 & 9.8 & 62.1 & 20.5 & 5.2 & 2.4 \\
\hline Mass \% & $\mathrm{Al}$ & $\mathrm{Co}$ & $\mathrm{Ni}$ & $\mathrm{Mo}$ & $\mathrm{Nb}$ \\
\hline Area 1 & 4.6 & 83.1 & - & 8.4 & 3.9 \\
\hline Area 2 & 4.5 & 62.6 & 20.6 & 8.5 & 3.8 \\
\hline
\end{tabular}

Fig. 5 Microstructure of $\mathrm{Co}-(\mathrm{Ni})-\mathrm{Al}-\mathrm{Mo}-\mathrm{Nb}$ alloys in as-solutionized state

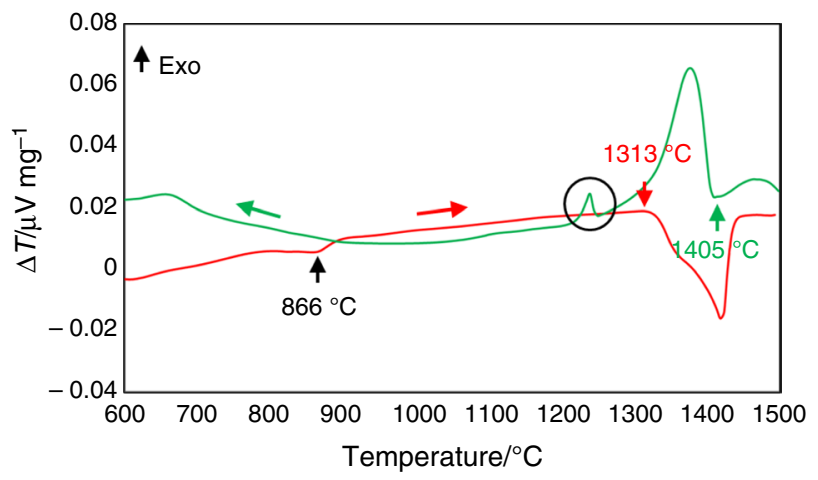

Fig. 6 Differential thermal analysis of $\mathrm{Co}-10 \mathrm{Al}-5 \mathrm{Mo}-2 \mathrm{Nb}$ alloy in as-solutionized state

effect was reported in the as-cast state. Moreover, the cooling plot did not reveal any effect corresponding to the $\gamma^{\prime}$ precipitation that was unexpected. The thermal analysis of Co-20Ni-10Al-5Mo-2Nb (at\%) alloy is be seen in Fig. 7 . The course of heating curve is analogous to that of heating plot of Ni-free alloy; however, the order-disorder transformation occurred at c.a. $100{ }^{\circ} \mathrm{C}$ higher temperature. The cooling plot did not reveal any precipitation effect, even the $\gamma^{\prime}$ precipitation that was also surprising. In order to verify the 


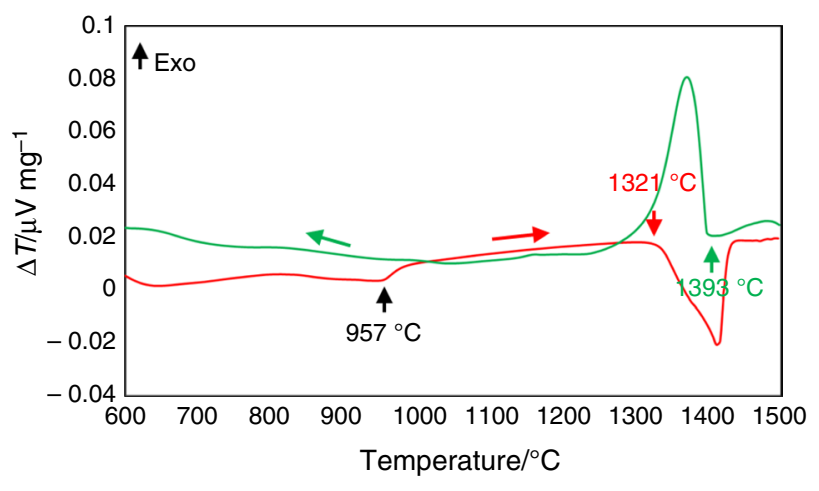

Fig. 7 Differential thermal analysis of $\mathrm{Co}-20 \mathrm{Ni}-10 \mathrm{Al}-5 \mathrm{Mo}-2 \mathrm{Nb}$ alloy in as-solutionized state

temperature of thermal effects connected with dissolution of the $\gamma^{\prime}$ phase, aging operations at different temperatures were performed for both alloys.

Figure 8 shows example SEM micrograph of Co-20Ni-10Al-5Mo-2Nb (at\%) alloy after aging. The microstructure composed of tiny cuboidal $\gamma^{\prime}$ precipitates is typical for such alloys after the precipitation hardening. In order to rate effectiveness of the aging, the hardness measurements were carried out (Fig. 9). The hardness of Ni-free alloy in the as-cast state measured by the Vickers method was $238 \mathrm{HV} 2.5$, whereas after the solution heat treatment, the hardness value decreased to $206 \mathrm{HV} 2.5$. After $5 \mathrm{~h}$ of aging at $800{ }^{\circ} \mathrm{C}$, the hardness of alloy reached c.a. 303 HV2.5. This result implies that the $\gamma-\gamma^{\prime}$ microstructure was obtained in this case. The aging operation in the temperature range of $850-1000{ }^{\circ} \mathrm{C}$ resulted in substantially lower hardness compared to that of after aging at $800{ }^{\circ} \mathrm{C}$. Therefore, temperature $850{ }^{\circ} \mathrm{C}$ and the higher ones could be too high for heat treatment and operation of this alloy, which is in accordance with the DTA analysis (Fig. 6), which revealed the effect related to dissolution of the $\gamma^{\prime}$ at $866{ }^{\circ} \mathrm{C}$. In the case of $\mathrm{Co}-20 \mathrm{Ni}-10 \mathrm{Al}-5 \mathrm{Mo}-2 \mathrm{Nb}$ (at\%) alloy, the value of hardness in the as-cast state was c.a. $257 \mathrm{HV} 2.5$, whereas the solutionizing of alloy at $1200^{\circ} \mathrm{C}$ decreased hardness to 237 HV2.5. The increase in hardness measured by Vickers method to c.a. $317 \mathrm{HV} 2.5$ was noted for the specimen aged at $800{ }^{\circ} \mathrm{C}$. High hardness was measured also after aging at $8500^{\circ} \mathrm{C}$ and $900{ }^{\circ} \mathrm{C}$ and reached c.a. 313 HV2.5 in both cases. The value of hardness of specimen aged at $950{ }^{\circ} \mathrm{C}$ was $218 \mathrm{HV} 2.5$, whereas after aging at $1000{ }^{\circ} \mathrm{C}$, the value of hardness was c.a. $213 \mathrm{HV} 2.5$. The obtained results imply that temperature $950{ }^{\circ} \mathrm{C}$ too created the $\gamma-\gamma^{\prime}$ microstructure in this alloy, which is in accordance with noticed endothermic thermal effect (Fig. 7) that implies the dissolution of $\gamma^{\prime}$ at $957^{\circ} \mathrm{C}$.

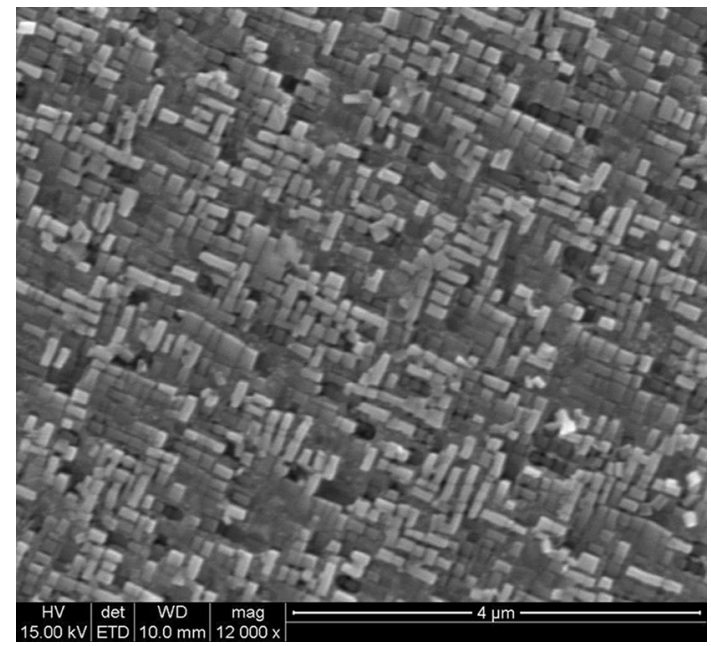

Fig. 8 SEM micrograph of $\mathrm{Co}-20 \mathrm{Ni}-10 \mathrm{Al}-5 \mathrm{Mo}-2 \mathrm{Nb}$ alloy after aging at $900{ }^{\circ} \mathrm{C}$

After aging, the thermal analysis was performed in order to investigate the solvus and solidus temperatures of alloys. Figure 10 shows the DTA plots of Co-10Al-5Mo-2Nb (at\%) alloy after aging at $800^{\circ} \mathrm{C}$ for $5 \mathrm{~h}$. The heating curve revealed three endothermic effects. The first one at $857^{\circ} \mathrm{C}$ corresponds to the order-disorder transformation, which indicates the solvus temperature. The second effect that occurred at $1175^{\circ} \mathrm{C}$ is similar to the effects observed earlier (Fig. 3); however, in this case, the endothermic effect occurred at lower temperature. The third effect is connected with start of alloy's melting, namely the solidus temperature, which is $1318{ }^{\circ} \mathrm{C}$ for the discussed alloy. The melting start effect corresponding to the solidus temperature is substantially lower compared to that of melting temperature of Co-9Al-9W (at\%) alloy $\left(1447^{\circ} \mathrm{C}\right)[12]$. The cooling curve showed that precipitation of the $\gamma^{\prime}$ starts at $845^{\circ} \mathrm{C}$ that is similar compared to the temperature of dissolution. It is worth to notice that effect related to the $\gamma^{\prime}$ precipitation was recorded at substantially lower temperature compared to that of as-cast state. The thermal analysis of Co-20Ni-10Al-5Mo-2Nb (at\%) alloy is shown in Fig. 11. In this case, the solvus temperature according to the heating curve is $944{ }^{\circ} \mathrm{C}$. Furthermore, the melting point of alloy according to DTA analysis is $1338{ }^{\circ} \mathrm{C}$. It is worth to notice that the exothermic effect connected with precipitation of the $\gamma^{\prime}$ occurred at $846{ }^{\circ} \mathrm{C}$ that is almost $100^{\circ} \mathrm{C}$ lower compared to that of analogous effect on heating curve. Therefore, the DSC analysis was performed in order to precisely investigate the thermal effect connected with ordering of $\gamma^{\prime}$ phase. Figure 12 shows the DSC plots corresponding to $\mathrm{Co}-10 \mathrm{Al}-5 \mathrm{Mo}-2 \mathrm{Nb}(\mathrm{at} \%)$ alloy after aging at $800{ }^{\circ} \mathrm{C}$ for 
Fig. 9 Vickers hardness of $\mathrm{Co}-(\mathrm{Ni})-\mathrm{Al}-\mathrm{Mo}-\mathrm{Nb}$ alloys after different heat treatment operations
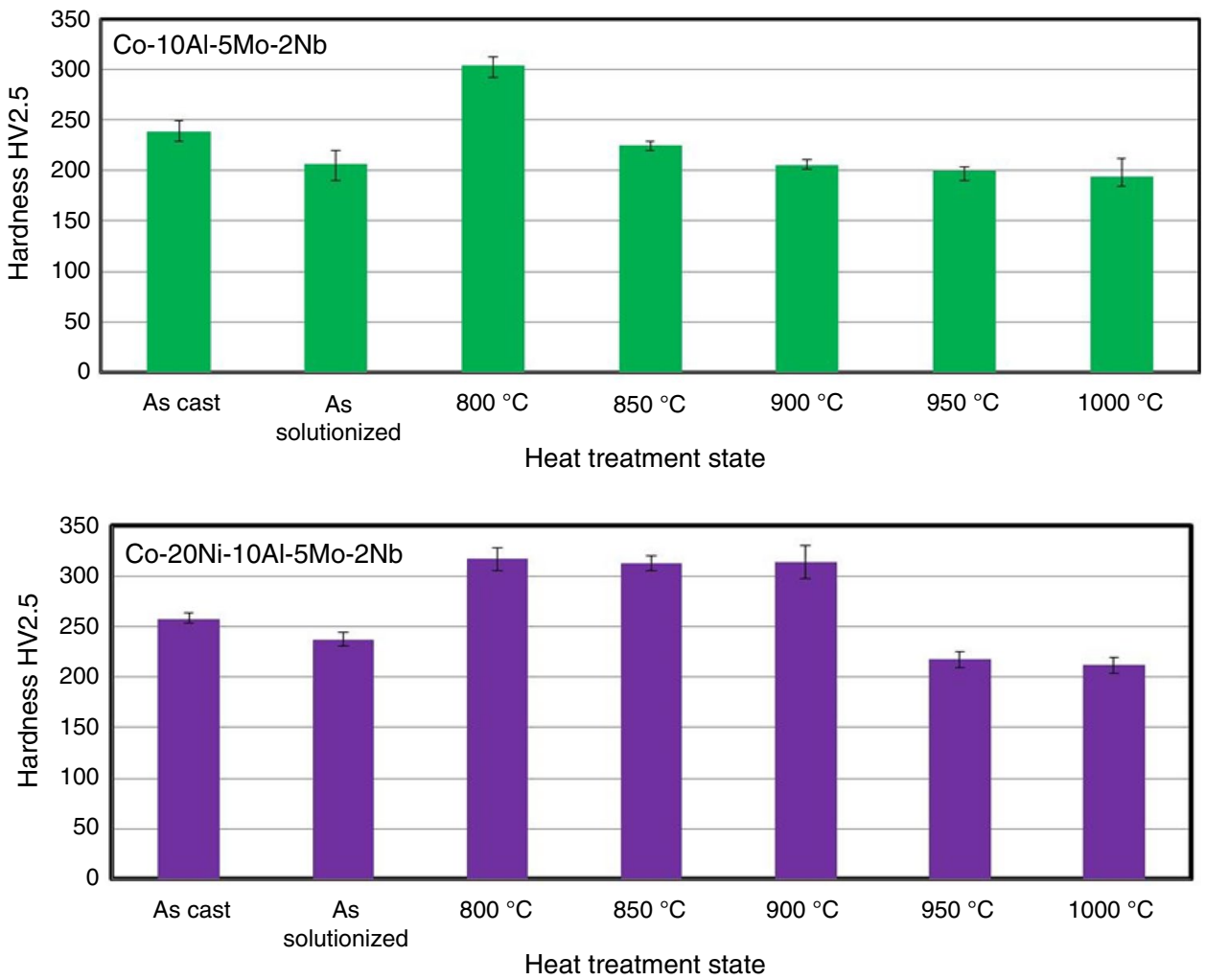

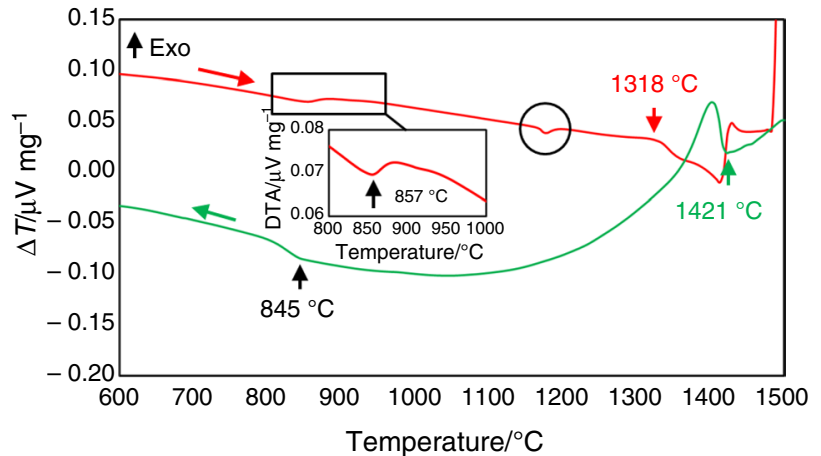

Fig. 10 Differential thermal analysis of $\mathrm{Co}-10 \mathrm{Al}-5 \mathrm{Mo}-2 \mathrm{Nb}$ alloy after aging at $800{ }^{\circ} \mathrm{C}$

$5 \mathrm{~h}$. The solvus temperature determined using heating curve $\left(861{ }^{\circ} \mathrm{C}\right)$ was close to that of indicated by DTA (Fig. 8), whereas the temperature of reversible effect during cooling $\left(845^{\circ} \mathrm{C}\right)$ was almost the same in the case of DTA and DSC methods. Furthermore, some endothermic effect (indicated by black circle) was observed at $718{ }^{\circ} \mathrm{C}$. Such peak is characteristic for magnetic transformation in cobalt and its alloys. Cooling curve showed reversible effect; however, its

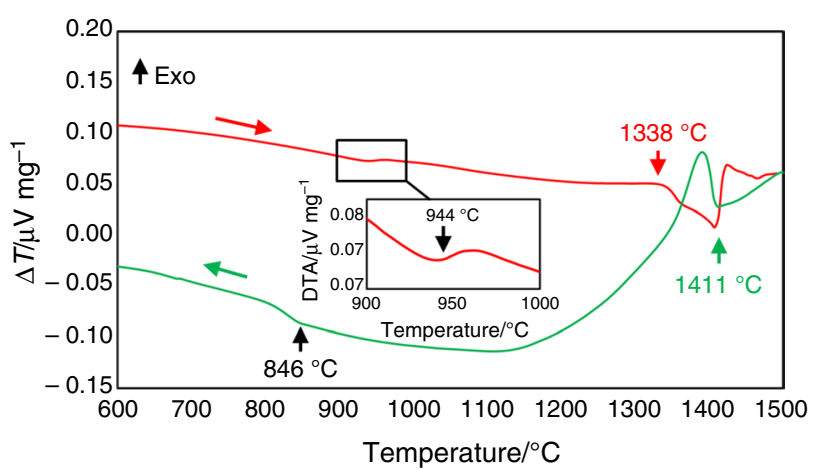

Fig. 11 Differential thermal analysis of $\mathrm{Co}-20 \mathrm{Ni}-10 \mathrm{Al}-5 \mathrm{Mo}-2 \mathrm{Nb}$ alloy after aging at $800{ }^{\circ} \mathrm{C}$

intensity was slight. Figure 13 shows the analogous DSC analysis of alloy containing $\mathrm{Ni}$. In this case, the solvus temperature indicated by the heating curve was $950{ }^{\circ} \mathrm{C}$. The cooling curve showed the exothermic effect related to formation of the $\gamma^{\prime}$ phase at $942{ }^{\circ} \mathrm{C}$. The effects connected with magnetic transformation were observed also in this case. 
Fig. 12 Differential scanning calorimetry of $\mathrm{Co}-10 \mathrm{Al}-5 \mathrm{Mo}-$ $2 \mathrm{Nb}$ alloy after aging at $800^{\circ} \mathrm{C}$

Fig. 13 Differential scanning calorimetry of $\mathrm{Co}-20 \mathrm{Ni}-10 \mathrm{Al}-$ $5 \mathrm{Mo}-2 \mathrm{Nb}$ alloy after aging at $800{ }^{\circ} \mathrm{C}$
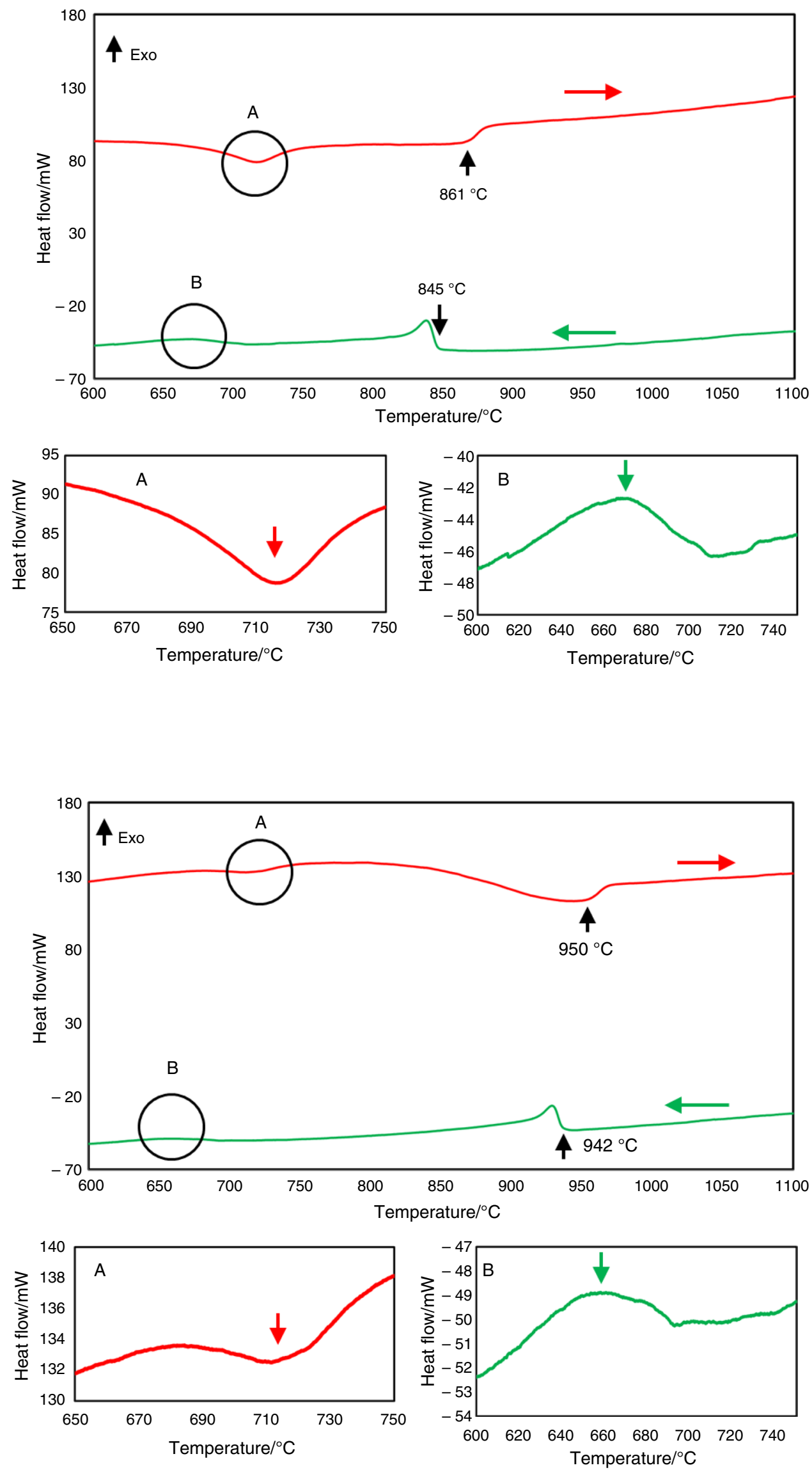


\section{Conclusions}

The presented analysis revealed many different thermal effects related to different structural processes in $\mathrm{W}$-free cobalt superalloys based on $\mathrm{Co}-\mathrm{Al}-\mathrm{Mo}-\mathrm{Nb}$ and $\mathrm{Co}-\mathrm{Ni}-\mathrm{Al}-\mathrm{Mo}-\mathrm{Nb}$ systems. The first difference between $\mathrm{Co}-(\mathrm{Ni})-\mathrm{Al}-\mathrm{W}$ alloys and alloys containing $\mathrm{Mo}$ and $\mathrm{Nb}$ was in the primary microstructure. In the case of W-free alloys, some detrimental Mo- and Nb-rich phases were observed in the interdendritic areas. Moreover, the thermal analysis revealed precipitation of some phases in the temperature range of $1200-1250{ }^{\circ} \mathrm{C}$. Except microstructural aspect, $\mathrm{W}$-replacement affected the thermal behavior of alloys.

The solidus temperature of both $\mathrm{W}$-free alloys was about $100{ }^{\circ} \mathrm{C}$ lower compared to that of Co-9Al-9W (at\%) alloy [12]. Substitution of $\mathrm{W}$ by Mo and $\mathrm{Nb}$ allows to obtain the $\gamma-\gamma^{\prime}$ microstructure. However, the solvus temperature $\left(861{ }^{\circ} \mathrm{C}\right)$ for $\mathrm{Co}-\mathrm{Al}-\mathrm{Mo}-\mathrm{Nb}$ alloy is substantially lower compared to that of $\mathrm{Co}-\mathrm{Al}-\mathrm{W}$ alloys $\left(\sim 990^{\circ} \mathrm{C}\right)$ [2]. Moreover, the $\gamma^{\prime}$ phase is not stable during long-term annealing [14] and requires stabilization by other elements.

The solvus temperature For $\mathrm{Co}-20 \mathrm{Ni}-10 \mathrm{Al}-5 \mathrm{Mo}-2 \mathrm{Nb}$ (at\%) alloy was c.a. $90{ }^{\circ} \mathrm{C}$ higher compared to that of Nifree Co-based alloy. It is in accordance with fact that nickel alloying extends the range of $\gamma^{\prime}$ occurrence in Co-alloys [17]. Furthermore, the solidus temperature of Ni-containing alloy was slightly higher compared to that of $\mathrm{Co}-10 \mathrm{Al}-5 \mathrm{Mo}-2 \mathrm{Nb}$ (at\%).

Acknowledgements This work was supported by National Science Centre (Project 2018/29/N/ST8/02062). Publication was supported by the Rector's Grant in the field of research and development, Silesian University of Technology, Grant Number 11/030/RGJ19/0234.

Open Access This article is licensed under a Creative Commons Attribution 4.0 International License, which permits use, sharing, adaptation, distribution and reproduction in any medium or format, as long as you give appropriate credit to the original author(s) and the source, provide a link to the Creative Commons licence, and indicate if changes were made. The images or other third party material in this article are included in the article's Creative Commons licence, unless indicated otherwise in a credit line to the material. If material is not included in the article's Creative Commons licence and your intended use is not permitted by statutory regulation or exceeds the permitted use, you will need to obtain permission directly from the copyright holder. To view a copy of this licence, visit http://creativecommons.org/licenses/by/4.0/.

\section{References}

1. Lee CS. Precipitation-hardening characteristics of ternary cobaltaluminum-X alloys. Tucson: University of Arizona; 1971.

2. Sato J, Omori T, Oikawa K, Ohnuma I, Kainuma R, Ishida K. Cobalt-base high-temperature alloys. Science. 2006;312:90-1.
3. Makineni SK, Nithin B, Chattopadhyay K. A new tungsten-free $\gamma-\gamma^{\prime}$ Co-Al-Mo-Nb-based superalloy. Scr Mater. 2014;98:36-9.

4. Nithin B, Samanta A, Makineni SK, Alam T, Pandey P, Abhishek K, Banerjee R, Chattopadhyay K. Effect of Cr addition on $\gamma-\gamma^{\prime}$ cobalt-based Co-Mo-Al-Ta class of superalloys: a combined experimental and computational study. J Mater Sci. 2017;52:11036-47.

5. Epishin A, Petrushin N, Nolze G, Gerstein G, Maier HJ. Investigation of the $\gamma^{\prime}$-strengthened quaternary co-based alloys Co-Al-WTa. Metall Mater Trans. 2018;49A:4042-57.

6. Bocchini PJ, Sudbrack ChK, Noebe RD, Seidman DN. Temporal evolution of a model $\mathrm{Co}-\mathrm{Al}-\mathrm{W}$ superalloy aged at $650^{\circ} \mathrm{C}$ and 750 ${ }^{\circ}$. Acta Mater. 2018;159:197-208.

7. Pyczak F, Bauer A, Göken M, Lorenz U, Neumeier S, Oehring M, Paul J, Schell N, Schreyer A, Stark A, Symanzik F. The effect of tungsten content on the properties of L12-hardened Co-Al-W alloys. J Alloys Compd. 2015;632:110-5.

8. Zenk CH, Neumeier S, Stone HJ, Göken M. Mechanical properties and lattice misfit of $\gamma-\gamma^{\prime}$ strengthened Co-base superalloys in the Co-W-Al-Ti quaternary system. Intermetallics. 2014;55:28-39.

9. Bocchini PJ, Sudbrack ChK, Sauza DJ, Noebe RD, Seidman DN, Dunand DC. Effect of tungsten concentration on microstructures of Co-10Ni-6Al- $(0,2,4,6) \mathrm{W}-6 \mathrm{Ti}$ (at\%) cobalt-based superalloys. Mater Sci Eng, A. 2017;700:481-6.

10. Xue F, Wang M, Feng Q. Alloying effects on heat-treated microstructure in $\mathrm{Co}-\mathrm{Al}-\mathrm{W}$-base superalloys at $1300^{\circ} \mathrm{C}$ and $900^{\circ} \mathrm{C}$. In: Huron ES, Reed RC, Hardy MC, Mills MJ, Montero RE, Portella PD, Telesman J, editors. Superalloys 2012, 12th international symposium on superalloys. Pittsburgh: TSM (The Minerlas, Materials \& Metals Society); 2012. p. 813-21.

11. Bocchini PJ, Sudbrack ChK, Noebe RD, Dunand DC, Seidman DN. Effects of titanium substitutions for aluminum and tungsten in Co-10Ni-9Al-9 W (at\%) superalloys. Mater Sci Eng, A. 2017;705:122-32.

12. Tomaszewska A, Moskal G, Migas D, Mikuśkiewicz M, Maciąg $\mathrm{T}$. Thermal parameters determination of $\mathrm{Co}-\mathrm{Al}-\mathrm{W}$ as-cast alloy homogenization by DTA analysis. J Therm Anal Calorim. 2018;134:157-64.

13. Makineni SK, Nithin B, Chattopadhyay K. Synthesis of a new tungsten-free $\gamma / \gamma^{\prime}$ cobalt-based superalloy by tuning alloying additions. Acta Mater. 2015;85:85-94.

14. Makineni SK, Nithin B, Chattopadhyay K. Phase evolution and crystallography of precipitates during decomposition of new "tungsten-free" $\mathrm{Co}(\mathrm{Ni})-\mathrm{Mo}-\mathrm{Al}-\mathrm{Nb} \gamma-\gamma^{\prime}$ superalloys at elevated temperatures. J Mater Sci. 2016;51:7843-60.

15. Mikuszewski T, Tomaszewska A, Moskal G, Migas D, Niemiec D. Primary microstructure characterization of new type $\gamma-\gamma^{\prime} \mathrm{Co}-$ Al-W cobalt-based superalloys. Mater Eng. 2017;5:217-23.

16. Hari Kumar KC, Ansara I, Wollants P, Delaey L. Thermodynamic optimisation of the $\mathrm{Co}-\mathrm{Nb}$ system. J Alloys Compd. 1998;267:105-12.

17. Li W, Li L, Stoichko A, Feng Q. Effective design of a Co-NiAl-W-Ta-Ti alloy with high $\gamma^{\prime}$ solvus temperature and microstructural stability using combined CALPHAD and experimental approaches. Mater Des. 2019;180:107912.

Publisher's Note Springer Nature remains neutral with regard to jurisdictional claims in published maps and institutional affiliations. 